\title{
The Impact of Population Age Structure on Real Estates Price-Evidence from China Provincial Panel Data
}

\author{
Yongrui Zheng \\ School of Economics, Jinan University, Guangzhou, China \\ Email: Alligator35@163.com
}

How to cite this paper: Zheng, Y.R. (2017) The Impact of Population Age Structure on Real Estates Price-Evidence from China Provincial Panel Data. Open Journal of Social Sciences, 5, 212-222. https://doi.org/10.4236/jss.2017.53019

Received: March 1, 2017

Accepted: March 25, 2017

Published: March 28, 2017

Copyright $\odot 2017$ by author and Scientific Research Publishing Inc. This work is licensed under the Creative Commons Attribution International License (CC BY 4.0).

http://creativecommons.org/licenses/by/4.0/ (c) (i) Open Access

\begin{abstract}
As "demographic dividend" gradually disappears, and two-child policy boosts, and the prototype of the aging society gradually shows, changes in population age structure in our country may appear. While the change of population age structure will affect the demand for housing, and then affect the price of housing. This article will make use of 2004-2014 provincial panel data of 31 provinces, cities and autonomous regions, in the control of variables: per capita income, housing supply factors, inflation, whole population to study the effects of population age structure on real estate prices. With the study, it was found that total dependency ratio and elderly dependency ratio are on an inverse relationship towards ordinary residence price. In particular, elderly dependency ratio is negatively related to high-grade residential property prices. On the further study, I found that the eastern region real estate price is most sensitive to the changes in the dependency ratio.
\end{abstract}

\section{Keywords}

Real Estates Price, Dependency Ratio, Provincial Panel Data, Population Age Structure, Per Capita Income

\section{Introduction}

In recent years, rising house prices peremptorily have become a serious problem of China's economic development, and even affect social stability. From 1998 to 2014, commercial housing average prices in our country rose from 2063 yuan per centiare up to 6323 yuan per centiare. The ascensional range is up to $206.5 \%$. While comparing to another index-CPI, from 1998 to 2014, if we took 1998 as the base, the CPI rose by only $38.39 \%$.

Behind the high housing prices, of course, there are many factors. Above all, 
house is a commodity. According to the law of value in political economy, commodity prices are determined by the value, and are influenced by supply and demand. So we firstly consider the value of it. However, in terms of the value of the land itself, it is difficult for us to illuminate that land value of Guangdong area is higher than that of Xinjiang region, and land value of Guizhou district is lower than that in the Beijing area. Value is condensation of undifferentiated human labor in the goods and it is decided by social necessary labor time. And the time needed for reclaiming a piece of land to build houses is almost the same. Therefore, house prices in different regions in the final analysis are caused by the imbalance between supply and demand. As Alchian (1964) in a classic aphorism says, "price, is the result of competition between buyers and buyers, sellers and sellers". The nature of house is meeting the demand of people's living, combined with the degree of marketization of real estate industry in our country continuing to improve; demand-orientation has become an important factor on promoting house prices in our country.

Housing demand is related to many factors, of which depends partly on the population characteristics, so under the special condition of "two children" policy and the coming aging society, the analysis of the impact of population age structure changes on real estate prices in China, with corresponding suggestions for the future population trends impact on housing prices, has strong practical significance.

On the following study, the article is divided into the several parts: firstly, the article would comb the literatures from foreign and domestic angles in order to summarize which factors can affect real estate price and influence mechanism; secondly, the article will analyze the theory which supports the empirical study; thirdly, based on the theory, the article will carry the empirical test and discuss the result. Finally, the article will give some suggestions based on the empirical results.

\section{Literature Review}

Literatures at home and abroad to study the effect of population age structure changes on real estate prices abound.

On the foreign part, Gregory Mankiw and David Weil [1] for the first time carried a systematic study of impact of population change, especially in the family birth peak and trough stage on the future housing market. Research has found that adults born during the "baby boomers" stage in the United States after World War II promoted property prices in the 1970s, and "the baby bust" would make the fall in house prices after the 1990s. It mainly reflects the demand of the population of baby boomers entering adulthood for housing. He thinks that the population of around 30 years old, is one of the largest housing demand groups. What's more, people's housing demand decreases after their 40 s, which leads to substantial of housing price falls. Ohtake and Shintanib [2] used the population age structure model that Mankiw and Weil carried of the impact on housing demand for Japanese condition, through cointegration tests 
and error correction model to analyze the relationship between population age structure and the housing price, and drew the similar conclusions to Mankiw and Weil. And then they predicted the impact of the change of population age structure on real estate market trend in the future. However, Engelhardt and Poterba [3] found that although the population structure is very similar with the United States, the actual housing prices showed a different path in Canada by studying the relationship between actual housing price and residential demand changes caused by the population changes after World War II. Although the Mankiw-Weil model is very classic, the Mankiw-Weil model only considered the impact of the population age structure characteristics on the real estate market, so the results vary from each other when considering different countries. Ermisch [4] started to modify the model, considering the influence of other variables such as income and the supply of house, then he controlled the variables of income and the supply of house, etc., finding that the population age structure carries significant impact on housing demand, and argued that with the aging population increasing, housing demand would decrease and housing prices would fall. Levin [5] revised Mankiw-Weil model from another angle, using time series data of England and Scotland with the control variables of wealth and income, and carried the conclusion that shrinking population and aging population would have downward pressure on housing demand and prices.

Domestic research literature on the impact of population age structure changes on real estate prices carried mainly after the 1998, this is mainly because the welfare housing distribution system abolished in 1998. Before 1998, real estate market was controlled in planned economy, which means market factors-supply and demand contributes less on the housing prices. Ha Jiming [6], put forward the viewpoint that "population structure dominates house prices", he thought that the population age structure has direct influence on asset prices include real estate prices. When a country stays in the stage with low dependency ratio, high savings rate, consumption rate is low, the investment rate is high and the house price rises. The author also believed that after the population age structure changes, the demographic dividend would transfer into demographic debt, and then asset prices would face downward pressure. Wang Qin and Jiang Man [7], carried a quantitative analysis by Logarithmic curve model and confirmed the views of the Ha Jiming, finding that the decline of population who has the demand in purchasing house would lead to downward pressure of house prices and. However, the research of Shi Qingqing carried the results that demographic dividend yield has nothing to do with real estate which means the impact of dependency ratio on the real estate market is not obvious. Xu Jianqiao, $\mathrm{Xu}$ Qiyuan and He fan [8] further distinguished elderly dependency ratio and the dependency ratio. From the population structure change angle, the author analyzed the reasons of over-lasting high house prices phenomenon, finding that, aging population bring-up ratio differs from children's dependency ratio, carrying positive relationship towards house prices in the actual situation of China. Chen Zhike, studied the impact of population age structure on house 
prices in Hunan province, which supports the point of He Jianqiao-he thought that the arrival of aging society, would influence the real estate market. Thus the increase of elderly dependency ratio can produce stimulation to house prices.

To sum up, the literature about the impact of population age structure on real estate prices at home and abroad abounds. While in terms of abroad, the first category is the cross section data, such as Mankiw and Weil [1]. The second type is based on time series data, such as Lindh and Mahnberg, Levin [5]. However, panel data used to study is very little, and in terms of domestic part, conclusions about the impact of population age structure change on the real estate prices are not unified: negative correlation, positive correlation, and even no effect. At the same time, there is also less literature that studied "whether population age structure of the different parts has different influence the real estate prices in each district. Therefore, this article will take panel data of population age structure of 31 provinces, cities and autonomous regions of our country in 2004-2014 to make empirical research about the influence on the real estate price". Further, it will distinguish whether population age structure in different districts would carry different impact on real estate prices in different parts, in order to enrich the existing theories, and put forward relevant suggestions according to the special situations in our country.

\section{Theoretical Analysis}

Life-cycle hypothesis theory from economists Franco Modigliani, divides one's life into three stages: the period of children ( 0 - 21 years old), adults (21 - 75 years old), and old age (more than 75). Usually, the period of children has no source of income, and daily consumption mainly comes from family, so in this period cost is more than income, which is named negative savings. As an adult, income increases beyond consumption, which was made savings. And the more elderly the age is, the higher the saving rate goes. When coming to old age, the savings will reduce. And the rise of the age may lead to negative savings. From this perspective, that the working-age population is more or the raising population is less, named the "demographic dividend" stage may contribute to high economic development, light social burden, high social savings rate and as a result the ability of residents to purchase housing increases. In the practical circumstances of our country, the residents' savings mainly flow to the real estate market and the stock market, so housing is not only a kind of need, but also a kind of investment value. Therefore, under the stimulus of demand for housing and housing investment, home prices will face upward pressure under lower dependency.

\section{Empirical Analysis of Impact of Population Age Structure on Real Estate Prices}

\subsection{Specification of Model}

Many factors can affect the real estate price. While real estate is commodity essentially, according to the price decision mechanism of commodity, we divide 
influencing factors into demand factors and supply factors. In terms of demand side, we consider the economic fundamentals and demographic factors. For economic fundamentals, we mainly consider the residents' disposable income as well as CPI, this is because the housing demand is both consumption and investment, no matter from which aspect, disposable income will increase the demand of commodity housing. For demographic factors, besides considering the absolute population of each region, the population age structure is the main variable, and supply factors, we mainly consider the actual supply of residence. Factors that affect real estate price are shown in Figure 1.

In the empirical study of this paper, we use disposable income per capita variable (in the model named as income, the same below) to measure disposable income, population bring-up ratio (dr) to measure population age structure. In the population age structure, we use total population bring-up ratio (dr-t), young dependency ratio $(\mathrm{dr}-\mathrm{c})$, elderly dependency ratio (dr-o) to differentiate different age structure. When coming to demographic factors, we use total population (people) to measure absolute regional population, actual sale square of the residence area (square) to measure the actual supply of housing.

The actual sale price of each region (hp) is used to measure the real estate prices. This paper will adopt linear model to fitting regression, house prices is regarded as explained variables, population bring-up ratio as the explanatory variable, other variables as control variables, therefore, we set the model as:

$$
\begin{aligned}
& h p=c+\lambda_{1} d r-t+\lambda_{2} \text { people }+\lambda_{3} C P I+\lambda_{4} \text { square }+\lambda_{5} \text { income }+\varepsilon \\
& h p=c+\lambda_{1} d r-o+\lambda_{2} \text { people }+\lambda_{3} C P I+\lambda_{4} \text { square }+\lambda_{5} \text { income }+\varepsilon \\
& h p=c+\lambda_{1} d r-c+\lambda_{2} \text { people }+\lambda_{3} C P I+\lambda_{4} \text { square }+\lambda_{5} \text { income }+\varepsilon
\end{aligned}
$$

Note: $\varepsilon$ means random terms that affect real estate price.

After the regression of (1)-(3), in order to study the impact of population bring-up ratio on real estate price in different district, according to the classification method of China health statistics yearbook, Beijing, Tianjin, Hebei, Liaoning, Shanghai, Jiangsu, Zhejiang, Fujian, Shandong, Guangdong and Hainan totally 11 provinces and municipalities directly under the central government are divided into the eastern region; Shanxi, Jilin, Heilongjiang, Anhui, Jiangxi, Henan, Hubei, and Hunan totally 8 provinces are divided into the middle region; Sichuan, Chongqing, Guizhou, Yunan, Tibet, Shanxi, Gansu, Qinghai, Ningxia, Xinjiang, Guangxi and Inner Mongolia totally 12 provinces and municipalities directly under the central government are divided into the western region. Then Equation can further be expanded to:

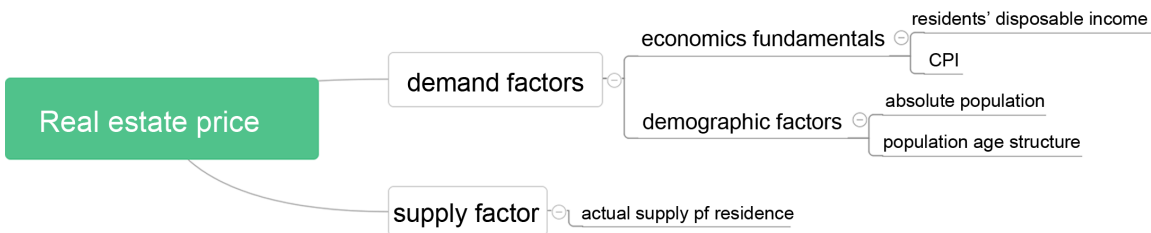

Figure 1. The factors that affect real estate price. 


$$
\begin{aligned}
& h p=c+\lambda_{1} d r-t_{i}+\lambda_{2} \text { people }_{i}+\lambda_{3} C P I+\lambda_{4} \text { square }_{i}+\lambda_{5} \text { income }_{i}+\varepsilon_{i} \\
& h p=c+\lambda_{1} d r-o_{i}+\lambda_{2} \text { people }_{i}+\lambda_{3} C P I+\lambda_{4} \text { square }_{i}+\lambda_{5} \text { income }_{i}+\varepsilon_{i} \\
& h p=c+\lambda_{1} d r-c_{i}+\lambda_{2} \text { people }_{i}+\lambda_{3} C P I+\lambda_{4} \text { square }_{i}+\lambda_{5} \text { income }_{i}+\varepsilon_{i}
\end{aligned}
$$

Note: $i$ can be represented respectively e (eastern), $\mathrm{m}$ (middle), w (western).

\subsection{Data Analysis}

Therefore, we adopt the panel data of 31 provinces and cities during 2004-2014, in the control variables of per capita disposable income, population, CPI, residential area, actual sale square, to research the impact of total bring-up ratio, young dependency ratio and elderly dependency ratio on the regional average commercial house price. The data of per capita disposable income, CPI, total population, population bring-up ratio, residential area of actual sales, commercial housing sales price variables are all from the national bureau of statistics.

Specifically, according to the China statistical yearbook, population bring-up ratio refers to proportion of the population from 0 to 14 years old and over 65 in aged 15 - 64 population, while elderly dependency ration refers to the proportion of the population aged over 65 in the population of 15 - 64, young dependency ratio refers to the proportion of 0 to 14 years in the population of $15-64$.

The descriptive statistics of all variables are shown in Table 1.

\section{Results and Discussion}

\subsection{Basic Regression}

Before the regression, we firstly analyze the correlation between explaining variable and explained variable. The results are shown in Table 2. From Table 2, we can see that elderly dependency ratio (dr-o), income, actual sale square (square) has positive correlation with house price (hp), while young dependency ratio (dr-c), total population bring-up ratio (dr-t), CPI, total population (people) has negative correlation with house price (hp).

Then we take the basic regression, using panel data from 2004-2014 of 31 provinces in our country. The results are shown in Table 3.

Table 3 shows us a lot of information about the regression. In line 1, according to Equation (1), we can see that the coefficient of total population ration

Table 1. The descriptive statistics.

\begin{tabular}{cccccc}
\hline Variable & mean & $\mathrm{N}$ & $\mathrm{min}$ & $\max$ & $\mathrm{sd}$ \\
\hline $\mathrm{dr}-\mathrm{o}$ & 12.26 & 341.00 & 6.71 & 20.31 & 2.45 \\
$\mathrm{dr}-\mathrm{c}$ & 24.15 & 341.00 & 9.64 & 44.65 & 7.14 \\
$\mathrm{dr}-\mathrm{t}$ & 36.40 & 341.00 & 19.27 & 57.58 & 6.96 \\
CPI & 103.12 & 341.00 & 97.65 & 110.09 & 1.99 \\
Income & $17,242.46$ & 341.00 & 7217.87 & $48,841.40$ & 7597.07 \\
square & 2532.89 & 341.00 & 9.56 & $10,191.52$ & 2059.74 \\
hp & 4433.88 & 341.00 & 1325.00 & $18,833.00$ & 3030.63 \\
\hline
\end{tabular}


Table 2. Correlative coefficient matrix of each variable.

\begin{tabular}{ccccccccc}
\hline & $\mathrm{hp}$ & $\mathrm{dr}-\mathrm{o}$ & $\mathrm{dr}-\mathrm{c}$ & $\mathrm{dr}-\mathrm{t}$ & $\mathrm{CPI}$ & income & people & square \\
\hline $\mathrm{hp}$ & 1 & & & & & & & \\
$\mathrm{dr}-\mathrm{o}$ & 0.0807 & 1 & & & & & & \\
$\mathrm{dr}-\mathrm{c}$ & -0.569 & -0.242 & 1 & & & & & \\
$\mathrm{dr}-\mathrm{t}$ & -0.554 & 0.106 & 0.939 & 1 & & & & \\
$\mathrm{CPI}$ & -0.0842 & -0.152 & 0.0742 & 0.0236 & 1 & & & \\
income & 0.861 & 0.144 & -0.538 & -0.499 & -0.0916 & 1 & & \\
people & -0.0853 & 0.322 & -0.0297 & 0.0840 & -0.0266 & 0.0702 & 1 & \\
square & 0.192 & 0.480 & -0.299 & -0.136 & -0.115 & 0.425 & 0.744 & 1 \\
\hline
\end{tabular}

Table 3. The results of basic regression.

\begin{tabular}{|c|c|c|c|}
\hline & (1) & (2) & (3) \\
\hline & total & old & child \\
\hline \multirow[t]{2}{*}{$\mathrm{dr}-\mathrm{t}$} & $-53.0435^{\star *}$ & & \\
\hline & $(0.034)$ & & \\
\hline \multirow[t]{2}{*}{ income } & $0.2547^{\star * *}$ & $0.2625^{\star * *}$ & $0.2665^{\star * *}$ \\
\hline & $(0.000)$ & $(0.000)$ & $(0.000)$ \\
\hline \multirow[t]{2}{*}{ CPI } & -0.9660 & -7.8466 & 8.9249 \\
\hline & $(0.937)$ & $(0.496)$ & $(0.465)$ \\
\hline \multirow{2}{*}{ people } & $1.2223^{*}$ & 0.7403 & $1.3305^{\star *}$ \\
\hline & $(0.056)$ & $(0.149)$ & $(0.028)$ \\
\hline \multirow[t]{2}{*}{ square } & $-0.2907^{\star *}$ & $-0.1818^{\star *}$ & $-0.3020^{* *}$ \\
\hline & $(0.019)$ & $(0.044)$ & $(0.011)$ \\
\hline \multirow[t]{2}{*}{ dr-o } & & $-2.4 \mathrm{e}+02^{\star * *}$ & \\
\hline & & $(0.000)$ & \\
\hline \multirow[t]{2}{*}{$\mathrm{dr}-\mathrm{c}$} & & & -5.9127 \\
\hline & & & $(0.824)$ \\
\hline \multirow[t]{2}{*}{ _cons } & $-2.4 \mathrm{e}+03$ & 965.2819 & $-5.8 \mathrm{e}+03^{*}$ \\
\hline & $(0.430)$ & $(0.628)$ & $(0.057)$ \\
\hline$N$ & 341 & 341 & 341 \\
\hline $\operatorname{adj} . R^{2}$ & 0.8479 & 0.8620 & 0.8431 \\
\hline $\mathrm{F}$ & 124.2835 & 156.9556 & 131.9280 \\
\hline
\end{tabular}

Note: Standard errors in parentheses. ${ }^{*} \mathrm{p}<0.10,{ }^{* *} \mathrm{p}<0.05,{ }^{* * *} \mathrm{p}<0.01$. It is drawn by Stata.

$(\mathrm{dr}-\mathrm{t})$ is negative to house price and significant in $5 \%$ significance level. It also expresses that if "dr-t" increase 1 unit, house price will decrease average by $53.0345 \%$. Other variables like income, is positive to house price and significant in $1 \%$ significance level, while actual sale housing square (square) is also negative and significant in $5 \%$ significance level. These tell us that income and housing supply are other important factors to stimulate house price. In line 2, according to Equation 2, we can see that the coefficient of elderly population ration ( $\mathrm{dr}-\mathrm{o})$ is negative to house price and significant in $1 \%$ significance level. It also expresses 
that if "dr-o" increase 1 unit, house price will decrease average by $240 \%$. What's more, income and housing supply (square) also plays a role in house price. In line 3 , we can see that the coefficient of young population ration $(\mathrm{dr}-\mathrm{c})$ is negative to house price but not significant. This mainly because children do no has demand to house, even though a new baby may indirectly stimulate to optimized house demand, while at that time, parents may stay under burden of bring up children, and have no more spare money to own another house.

\subsection{Regression Analysis of Different District}

In order to study the impact of population dependency ration on house price in different district, according to the classification method of China health statistics yearbook, we divide 31 provinces into eastern, middle and western area. Then carry further regression based on basic regression. Results are shown in Tables $4-6$.

From Tables 4-6, we can see that only population dependency ratio in eastern are significant in house price, like total dependency ratio and elderly dependency ratio are negative to house price and significant in $1 \%$ level. Even young dependency ratio play a role in fluctuation of house price. This mainly because the real estate market in eastern has early marketization, according to pricing mechanism, when commodity marketizes, it may be influenced by demand and supply, and population dependency ratio can be a part of demand factor. Population dependency ratio is not significant on house price.

Table 4. Regression of dr-t on each area.

\begin{tabular}{|c|c|c|c|}
\hline & (1) & (2) & (3) \\
\hline & hp (eastern) & hp (middle) & hp (western) \\
\hline \multirow[t]{2}{*}{$\mathrm{dr}-\mathrm{t}$} & $-1.5 \mathrm{e}+02^{\star * *}$ & -29.2055 & -15.6676 \\
\hline & $(0.003)$ & $(0.173)$ & $(0.401)$ \\
\hline \multirow[t]{2}{*}{ income } & $0.2813^{* * *}$ & $0.2025^{\star * *}$ & $0.1749^{* * *}$ \\
\hline & $(0.000)$ & $(0.000)$ & $(0.000)$ \\
\hline \multirow[t]{2}{*}{ CPI } & -16.5496 & 1.5395 & 2.8232 \\
\hline & $(0.668)$ & $(0.842)$ & $(0.792)$ \\
\hline \multirow[t]{2}{*}{ people } & 0.9813 & 0.0262 & -0.5167 \\
\hline & $(0.448)$ & $(0.935)$ & $(0.185)$ \\
\hline \multirow[t]{2}{*}{ square } & $-0.4017^{\star * *}$ & -0.0116 & $0.2188^{\star *}$ \\
\hline & $(0.007)$ & $(0.881)$ & $(0.022)$ \\
\hline \multirow[t]{2}{*}{ _cons } & $3.7 \mathrm{e}+03$ & 957.5840 & $2.1 \mathrm{e}+03$ \\
\hline & $(0.544)$ & $(0.642)$ & $(0.294)$ \\
\hline$N$ & 121 & 88 & 132 \\
\hline $\operatorname{adj} . R^{2}$ & 0.8678 & 0.9482 & 0.9397 \\
\hline $\mathrm{F}$ & 80.6754 & 195.9789 & 314.5502 \\
\hline
\end{tabular}

Note: Standard errors in parentheses. ${ }^{\star} \mathrm{p}<0.10,{ }^{* *} \mathrm{p}<0.05,{ }^{* * *} \mathrm{p}<0.01$. It is drawn by Stata. 
Table 5. Regression of dr-o on each area.

\begin{tabular}{|c|c|c|c|}
\hline & (1) & (2) & (3) \\
\hline & hp (eastern) & $\mathrm{hp}$ (middle) & $\mathrm{hp}$ (western) \\
\hline \multirow[t]{2}{*}{$\mathrm{dr}-\mathrm{c}$} & $-1.2 \mathrm{e}+02^{*}$ & -20.4553 & -12.5900 \\
\hline & $(0.084)$ & $(0.518)$ & $(0.559)$ \\
\hline \multirow[t]{2}{*}{ income } & $0.2942^{* * *}$ & $0.2023^{\star * *}$ & $0.1752^{* * *}$ \\
\hline & $(0.000)$ & $(0.000)$ & $(0.000)$ \\
\hline \multirow[t]{2}{*}{ CPI } & 0.4009 & 3.9279 & 4.1796 \\
\hline & $(0.991)$ & $(0.616)$ & $(0.704)$ \\
\hline \multirow[t]{2}{*}{ people } & 1.3068 & 0.1044 & -0.4773 \\
\hline & $(0.343)$ & $(0.753)$ & $(0.218)$ \\
\hline \multirow[t]{2}{*}{ square } & $-0.4762^{\star * *}$ & -0.0152 & $0.2179^{\star *}$ \\
\hline & $(0.003)$ & $(0.848)$ & $(0.023)$ \\
\hline \multirow[t]{2}{*}{ _cons } & $-2.1 \mathrm{e}+03$ & $-2.5 e+02$ & $1.6 \mathrm{e}+03$ \\
\hline & $(0.759)$ & $(0.909)$ & $(0.379)$ \\
\hline$N$ & 121 & 88 & 132 \\
\hline $\operatorname{adj} . R^{2}$ & 0.8564 & 0.9465 & 0.9393 \\
\hline $\mathrm{F}$ & 101.4981 & 153.3745 & 347.6965 \\
\hline
\end{tabular}

Note: Standard errors in parentheses. ${ }^{*} \mathrm{p}<0.10,{ }^{* *} \mathrm{p}<0.05,{ }^{* * *} \mathrm{p}<0.01$. It is drawn by Stata.

Table 6. Regression of dr-c on each area.

\begin{tabular}{|c|c|c|c|}
\hline & (1) & (2) & (3) \\
\hline & hp (eastern) & hp (middle) & hp (western) \\
\hline \multirow[t]{2}{*}{$\mathrm{dr}-\mathrm{c}$} & $-1.2 \mathrm{e}+02^{\star}$ & -20.4553 & -12.5900 \\
\hline & $(0.084)$ & $(0.518)$ & $(0.559)$ \\
\hline \multirow[t]{2}{*}{ income } & $0.2942^{\star * *}$ & $0.2023^{* * *}$ & $0.1752^{* * *}$ \\
\hline & $(0.000)$ & $(0.000)$ & $(0.000)$ \\
\hline \multirow[t]{2}{*}{ CPI } & 0.4009 & 3.9279 & 4.1796 \\
\hline & $(0.991)$ & $(0.616)$ & $(0.704)$ \\
\hline \multirow[t]{2}{*}{ people } & 1.3068 & 0.1044 & -0.4773 \\
\hline & $(0.343)$ & $(0.753)$ & $(0.218)$ \\
\hline \multirow[t]{2}{*}{ square } & $-0.4762^{\star * *}$ & -0.0152 & $0.2179^{* *}$ \\
\hline & $(0.003)$ & $(0.848)$ & $(0.023)$ \\
\hline \multirow{2}{*}{ _cons } & $-2.1 \mathrm{e}+03$ & $-2.5 e+02$ & $1.6 \mathrm{e}+03$ \\
\hline & $(0.759)$ & (0.909) & $(0.379)$ \\
\hline$N$ & 121 & 88 & 132 \\
\hline $\operatorname{adj} . R^{2}$ & 0.8564 & 0.9465 & 0.9393 \\
\hline $\mathrm{F}$ & 101.4981 & 153.3745 & 347.6965 \\
\hline
\end{tabular}

Note: Standard errors in parentheses. ${ }^{*} \mathrm{p}<0.10,{ }^{* *} \mathrm{p}<0.05,{ }^{* * *} \mathrm{p}<0.01$. It is drawn by Stata.

\section{Conclusion and Policy Implications}

This paper found that population dependency ratio does have effect on house 
price. The conclusions are as follows.

Firstly, the working-age population ratio has a significant positive role in house price because this portion of the population has strong demand on house. It may include the following several parts: 1) the crowd of young people especially those of age in marriage; 2) the crowd of people with high income who have demand to buy a larger house which replaces the one bought in youth;3) the crowd of people who have investment demand because the price is expected to continue to rise in the environment.

Secondly, the portion of aged people has negative influence on house price and young people have not significant influence on house price. This is mainly because when work-aged people run into aged people, it may decrease the demand of house and thus press house price. While young people run into work-aged people, it cannot have house demand instantly.

Thirdly, only population dependency ratio in eastern is significant in house price. The reasons are discussed above.

Based on the above research, this paper puts forward the following suggestions.

Firstly, to deploy regulation policy ahead of time in order to face the shock of people age structure change-the aging society will come in 2020s according to demographer.

Secondly, to implement more positive population birth policy to promote the stable demand for house-even though young dependency ratio has not significant effect on house price, if the portion of children increases rapidly, it may influence the work-aged population and then affect the demand of house and house price as well.

\section{Acknowledgements}

I am really grateful to the anonymous referees whose comments have significantly improved this paper.

\section{References}

[1] Mankiw, N.G. and Weil, D.N. (1989) The Baby Boom, the Baby Bust, and the Housing Market. Regional Science and Urban Economics, 19, 235-258. https://doi.org/10.1016/0166-0462(89)90005-7

[2] Ohtake, F. and Shintani, M. (1996) The Effect of Demographics on the Japanese Housing Market. Regional Science and Urban Economics, 26, 189-201. https://doi.org/10.1016/0166-0462(95)02113-2

[3] Engelhardt, G.V. and Poterba, J.M. (1991) House Prices and Demographic Change: Canadian Evidence. Regional Science and Urban Economics, 21, 539-546. https://doi.org/10.1016/0166-0462(91)90017-H

[4] Ermisch, J. (1996) The Demand for Housing in Britain and Population Ageing Microeconometric Evidence. Economica, 63, 383-404. https://doi.org/10.2307/2555013

[5] Levin, E., Montagnoli, A. and Wright, R.E. (2009) Demographic Change and the Housing Market: Evidence from a Comparison of Scotland and England. Urban Studies, 46, 27-43. https://doi.org/10.1177/0042098008098635 
[6] Ha, J.M. (2007) Population Structure and Urbanization Accelerate the Development of Real Estate. Real Estate Industry of China, No. 7, 28-29.

[7] Wang, Q. and Jiang, M. (2011) Population Age Structure and Housing Price Controls. Financial of Shanghai, No. 10, 15-22.

[8] Xu, J.W., Xu, Q.Y. and He, F. (2012) The Demographic Factors in House Price Rising: Evidence from International Experience and Chinese. World Economic, 1, 2442.

Submit or recommend next manuscript to SCIRP and we will provide best service for you:

Accepting pre-submission inquiries through Email, Facebook, LinkedIn, Twitter, etc. A wide selection of journals (inclusive of 9 subjects, more than 200 journals)

Providing 24-hour high-quality service

User-friendly online submission system

Fair and swift peer-review system

Efficient typesetting and proofreading procedure

Display of the result of downloads and visits, as well as the number of cited articles Maximum dissemination of your research work

Submit your manuscript at: http://papersubmission.scirp.org/

Or contact jss@scirp.org 